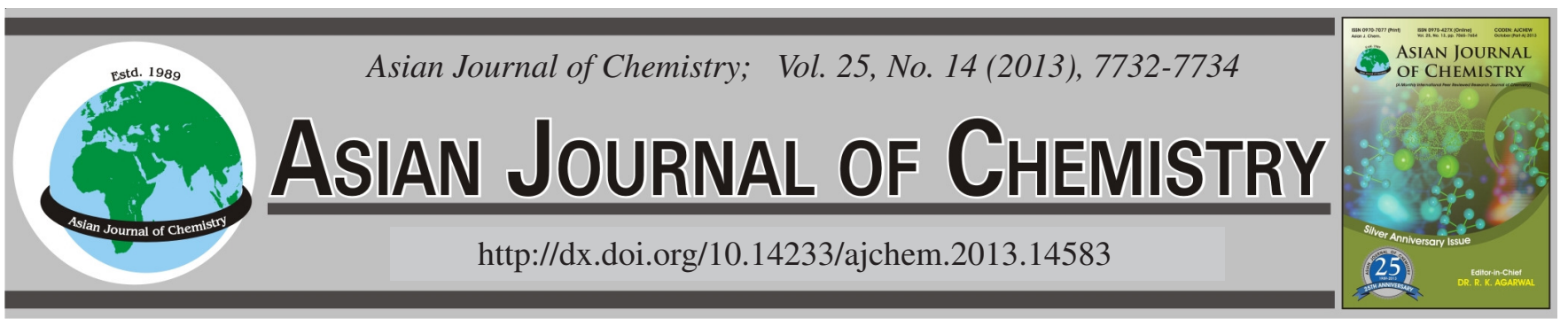

\title{
Removal of Chemical Contaminants of Micro-Polluted Water from Wastewater Treatment Plant Through Electrochemical Oxidation
}

\author{
HaO WAnG ${ }^{1, *}$, XUejin $\mathrm{Li}^{2}$ and ShuAngyan SONG ${ }^{3}$
}

${ }^{1}$ College of Civil and Architecture Engineering, Hebei United University, Tangshan, P.R. China

${ }^{2}$ Department of Foreign Languages, Tangshan College, Tangshan, P.R. China

${ }^{3}$ Xinchen Water Science Environmental Technology Co. Ltd., Beijing, P.R. China

*Corresponding author: E-mail: wanghao1689@gmail.com

(Received: 15 September 2012;

Accepted: 11 July 2013)

AJC-13796

\begin{abstract}
The electrochemical oxidation was adopted to further treat secondary effluent of wastewater treatment plants. The removal effect of major pollutants of constructed wetland effluent was mainly investigated and the main chemical reaction path of the removal of organic matter and nitrogen compounds by electrochemical method was discussed preliminarily. The results showed the best removal ratio of $\mathrm{NH}_{3}-\mathrm{N}_{\text {, }}$ total nitrogen and total phosphorus was $94.2,82.8$ and $60.5 \%$, respectively after dosing $\mathrm{NaCl}$ on the condition of different electrolysis time and constant current 5A (namely the current density $7.4 \mathrm{~mA} / \mathrm{cm}^{2}$ ). Meanwhile, the effect was better than no NaCl. If other experimental conditions remained unchanged, the major pollutants were removed faster by electrolysis. Considering power consumption, it suggested that the best operation condition was of some salt solution, the current density $7.4 \mathrm{~mA} / \mathrm{cm}^{2}$ and $0.5 \mathrm{~h}$.
\end{abstract}

Key Words: Secondary effluent of wastewater treatment plants, Electrolysis time, Electrochemical removel, Constructed wetland.

\section{INTRODUCTION}

Electrochemical oxidation treatment of water is a relatively new type of water treatment technology, which gradually develops into a very promising technology ${ }^{1,2}$. Because of easy controlling, lesser floor areas and no secondary pollution, it has been successfully applied in the purification of wastewater from many field of water treatment ${ }^{3-5}$. In addition, certain research experience to micro-polluted water using electrochemical method has been gained in the past several years. The experience proved that the method had great removals to $\mathrm{NH}_{3}-\mathrm{N}$ and total nitrogen ${ }^{6,7}$. Secondary effluent of wastewater treatment plants is further treated exiguously. In most instances, the effluent is directly discharge to rivers, and it will bring about river pollutions marginally ${ }^{8}$. Thus, the secondary effluent of wastewater treatment plants is necessary to be treated to reduce any possible impacts on rivers ${ }^{9-12}$.

Accordingly, this study focuses on using electrochemical method for treating secondary effluent of wastewater treatment plants. The electrochemical method was applied to advanced treatment of secondary effluent, and the hybrid process which made final effluent beat the target to environmental quality standards for surface water was discussed, too.

\section{EXPERIMENTAL}

Electrolytic system: A laboratory batch electrochemical oxidation reactor was designed and constructed to the dimensions shown in Fig. 1. The electrolytic cell was made of synthetic glass, with a dimension of $140 \mathrm{~mm} \times 90 \mathrm{~mm} \times 130 \mathrm{~mm}$, and the dimensions of the electrodes were $130 \mathrm{~mm} \times 65 \mathrm{~mm} \times$ $1 \mathrm{~mm}$. During electrolysis, the current density was adjusted by using a DC power supply (MPS702). The reactor consisted of an undivided cell made of synthetic glass with a cathode and anode arranged in parallel. Stainless steel plates were used as cathodes while, horizontal $\mathrm{Ti} / \mathrm{Ru} / \mathrm{Cr}$ plates acted as anodes. The electrodes were arranged in the electrochemical cell of $1 \mathrm{~L}$ working value.

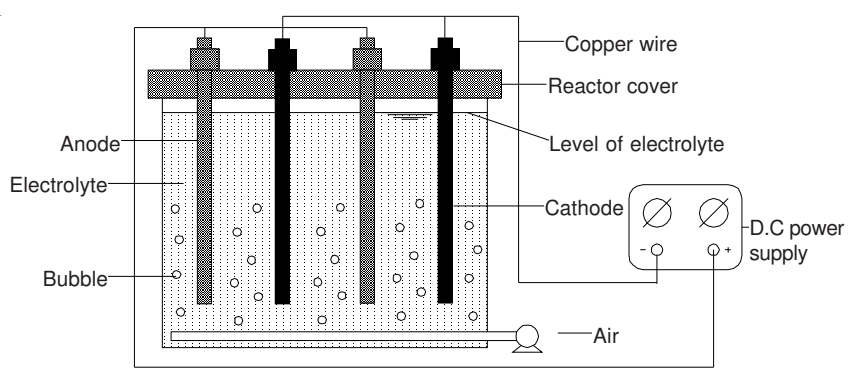

Fig. 1. Schematic diagram of the electrolytic system

Analytical methods: The experimental constants in electrolytic contaminants degradation were interelectrode distance, current density and initial $\mathrm{Cl}^{-}$concentration. The concentration of $\mathrm{NaCl}$ solution was $5.0 \mathrm{~mol} / \mathrm{L}$, the dosing ratio was $8 \mathrm{~mL} / \mathrm{h}$. 
And the removals of contaminants were changed at a time while the others were kept constant of definite salt concentration, the current density $7.4 \mathrm{~mA} / \mathrm{cm}^{2}$ and interelectrode distance $1 \mathrm{~cm}$.

Influent quality: The raw wastewater, secondary effluent of wastewater treatment plants, was collected from wastewater treatment plant in Tangshan. The composition of the influent used in all experiments is shown in Table- 1 .

\begin{tabular}{lcc} 
TABLE-1 \\
\multicolumn{3}{c}{$\begin{array}{c}\text { CHARACTERISTICS OF THE WASTEWATER } \\
\text { SAMPLE USED IN THE EXPERIMENTS }\end{array}$} \\
\hline \multicolumn{1}{c}{ Parameter } & Unit & Concentration \\
\hline $\mathrm{pH}$ & - & $7.2 \pm 0.2$ \\
Ammonia nitrogen $\left(\mathrm{NH}_{3}-\mathrm{N}\right)$ & $\mathrm{mg} \mathrm{L}^{-1}$ & $1.90 \pm 0.5$ \\
Total nitrogen (TN) & $\mathrm{mg} \mathrm{L}^{-1}$ & $3.25 \pm 0.9$ \\
Total phosphorus (TP) & $\mathrm{mg} \mathrm{L}^{-1}$ & $0.38 \pm 0.1$ \\
\hline
\end{tabular}

\section{RESULTS AND DISCUSSION}

Removal of nitrogenous compounds: As shown in Fig. 2 , when current density was $7.4 \mathrm{~mA} / \mathrm{cm}^{2}$ and the interelectrode distance was $1 \mathrm{~cm}$, the $\mathrm{NH}_{3}-\mathrm{N}$ and total nitrogen in constructed wetland were removed remarkably, too. Because of the lowconcentration $\mathrm{NH}_{3}-\mathrm{N}$, the removals of $\mathrm{NH}_{3}-\mathrm{N}$ with direct electrolysis were lower than the dosing $\mathrm{NaCl}$ solution. The maximum rates were 75.8 and $94.2 \%$, respectively. On the contrast, the maximum removal rates of total nitrogen were 71.4 and $82.8 \%$, the concentration of total nitrogen could attain $0.56 \mathrm{mg} / \mathrm{L}$ after dosing $\mathrm{NaCl}$ solution, which could satisfy the environmental quality standards for surface water to full advantage. In addition, the removals of the electrolytic oxidation of $\mathrm{NH}_{3}-\mathrm{N}$ and total nitrogen increase generally with the retention time, too. Meanwhile, the removal principles of $\mathrm{NH}_{3}-\mathrm{N}$ and total nitrogen is that dosing $\mathrm{NaCl}$ solution could accelerate the rates of generating oxidizability substances, so it had higher removals to certain contaminants. The oxidizing ability of electrodes attained the relative limit when the electrolysis time was $0.5 \mathrm{~h}$. At that time, the reduced oxidizability substances made the oxidation rate slacken remarkably, so the removals of $\mathrm{NH}_{3}-\mathrm{N}$ and total nitrogen increased tardily. But the effluent concentration had been satisfied our demand. The processes not only ensured the removal effects, but also saved the energy consumption, too.

Removal of total phosphorus: As is shown in Fig. 3, when current density was $7.4 \mathrm{~mA} / \mathrm{cm}^{2}$ and the interelectrode distance was $1 \mathrm{~cm}$, the total phosphorus was also removed remarkably. The removals of $\mathrm{NH}_{3}-\mathrm{N}$ with direct electrolysis were lower than the dosing $\mathrm{NaCl}$ solution. The maximum rates were 60.5 and $42.1 \%$, respectively. The concentration of total phosphorus could attain $0.15 \mathrm{mg} / \mathrm{L}$ after dosing $\mathrm{NaCl}$ solution. According above stated, when the electrolysis time exceeded $0.5 \mathrm{~h}$, the removals of total phosphorus increased tardily, too. In addition, the removals of phosphorus may be related to the electro-flocculation.

Course of chemical reaction: During electrolytic reaction, $\mathrm{O}_{2}$ was generated by the anode and dissolved oxygen in wastewater generated $\mathrm{H}_{2} \mathrm{O}_{2}$ at the cathode.

$$
\mathrm{O}_{2}+\mathrm{e}^{-} \longrightarrow \mathrm{O}_{2}^{-}
$$

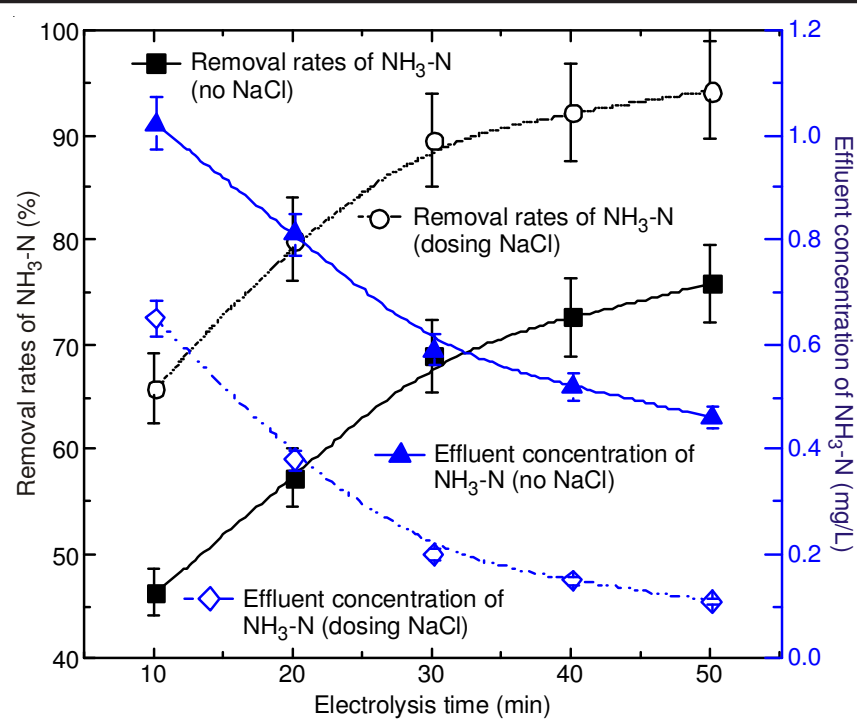

(a)

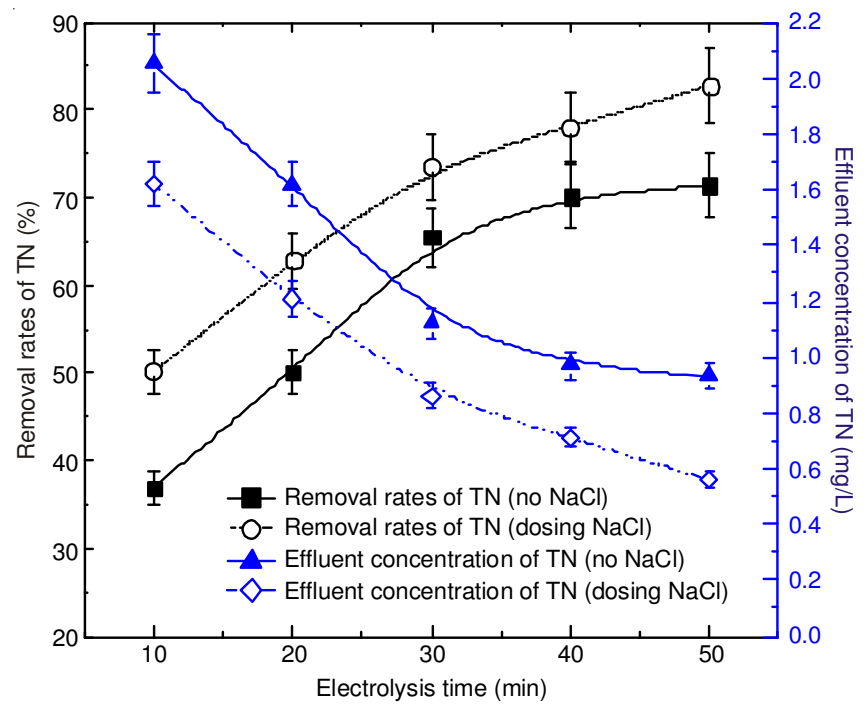

(b)

Fig. 2. Removal effect of nitrogenous compounds was showed when the electric current was constant with the electrolysis time prolonging

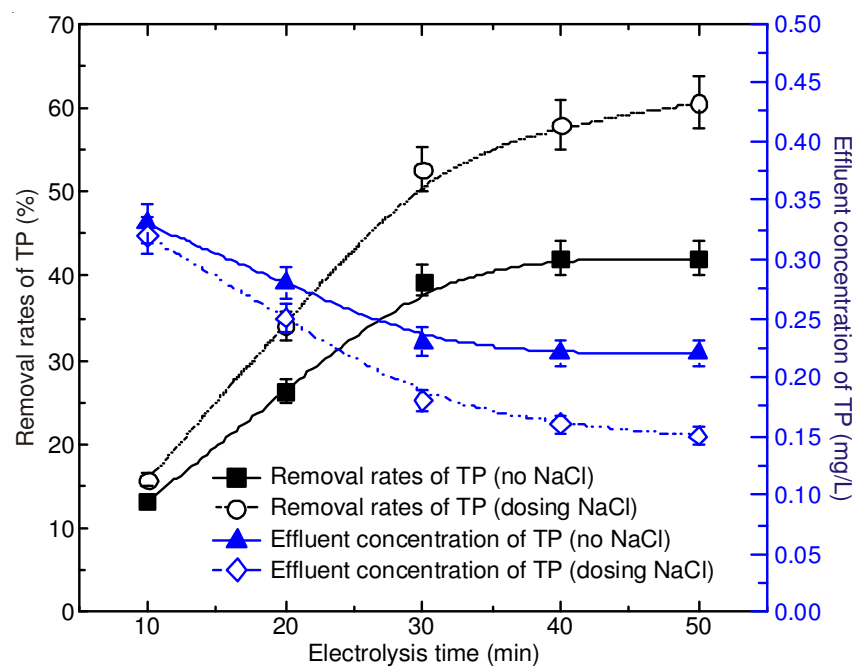

Fig. 3. Removal effect of total phosphorus was showed when the current density was constant with the electrolysis time prolonging 


$$
\begin{gathered}
\mathrm{O}_{2}^{-}+\mathrm{H}^{+} \longrightarrow \mathrm{H}_{2} \mathrm{O}^{\bullet} \\
2 \mathrm{H}_{2} \mathrm{O}^{\bullet} \longrightarrow \mathrm{H}_{2} \mathrm{O}_{2}+\mathrm{O}_{2}
\end{gathered}
$$

Another course of chemical reaction may possibly happen,

$$
\begin{gathered}
\mathrm{O}_{2}^{-}+\mathrm{H}_{2} \mathrm{O}^{\bullet} \longrightarrow \mathrm{O}_{2}+\mathrm{H}_{2} \mathrm{O}^{-} \\
\mathrm{H}_{2} \mathrm{O}^{-}+\mathrm{H}^{+} \longrightarrow \mathrm{H}_{2} \mathrm{O}_{2}
\end{gathered}
$$

and $\mathrm{HO}^{\circ}$, hydroxyl free radical was generated further by $\mathrm{H}_{2} \mathrm{O}_{2}$.

$$
\mathrm{H}_{2} \mathrm{O}_{2}+\mathrm{e}^{-} \longrightarrow \mathrm{HO}^{-}+\mathrm{HO}^{\bullet}
$$

$\mathrm{HO}^{\bullet}$ could oxidize organic and nitrogenous compounds and the overall reaction occurring in the anodic solution between hypochlorite and ammonia can be expressed as follows:

$$
2 \mathrm{NH}_{4}{ }^{+}+3 \mathrm{ClO}^{-} \longrightarrow \mathrm{N}_{2}+3 \mathrm{H}_{2} \mathrm{O}+2 \mathrm{H}^{+}+3 \mathrm{Cl}^{-}
$$

\section{Conclusion}

The experimental results indicated that the best operating condition was of some salt solution, the current density 7.4 $\mathrm{mA} / \mathrm{cm}^{2}$ and electrolysis time $0.5 \mathrm{~h}$. In addition, the removals of contaminants with direct electrolysis were lower than the dosing $\mathrm{NaCl}$ solution. Moreover, the results showed the best removal ratio of $\mathrm{NH}_{3}-\mathrm{N}$, total nitrogen and total phosphorus were $94.2,82.8$ and $60.5 \%$, respectively after dosing $\mathrm{NaCl}$ on the condition of different electrolysis time and constant current $5 \mathrm{~A}$ (namely the current density $7.4 \mathrm{~mA} / \mathrm{cm}^{2}$ ). The main indexes of electrolysis effluent could satisfy the environmental quality standards for surface water to a great extent.

\section{ACKNOWLEDGEMENTS}

The financial support of this research by Hebei Construction Science and Technology Research Program (2013-143) in P.R. China and Scientific Research Foundation for Doctor of HEUU (35394701) are gratefully acknowledged.

\section{REFERENCES}

1. N. Mehrdadi, A. Rahmani, A.A. Azimi and A. Torabian, Asian J. Chem., 21, 5245 (2009).

2. C.C. Tanner, J.P.S. Sukias and P.U. Martin, Water Res., 32, 3046 (2007).

3. H. Wang and L. Zhang, Asian J. Chem., 24, 5299 (2012).

4. G.D. Ji, T.H. Sun, Q.X. Zhou, X. Sui, S.J. Chang and P.J. Li, Ecol. Eng., 18, 459 (2002).

5. H. Wang, X.W. He, T.Q. Liu and C.H. Zhang, Fresen. Environ. Bull., 20, 2890 (2011).

6. Y.F. Lin, S.R. Jing, D.Y. Lee and T.W. Wang, Aquaculture, 209, 169 (2002).

7. J. Chang, X.H. Zhang and R. Perfler, Fresen. Environ. Bull., 16, 1082 (2007).

8. P.A. Mays, and G.S. Edwards, Ecol. Eng., 16, 487 (2001).

9. F. Rivera, A. Warren and C.R. Curds, Water Sci. Technol., 35, 271 (1997).

10. C.L. Yue, J. Chang and Y. Ge, Fresen. Environ. Bull., 17, 992 (2008).

11. N. Korboulewsky, R.Y. Wang and V. Baldy, Bioresour. Technol., 105, 9 (2012).

12. C.J. Richardson and S.S. Qian, Environ. Sci. Technol., 33, 1545 (1999). 